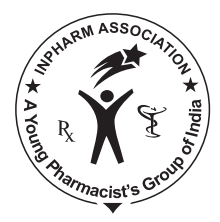

\title{
A Novel Extraction Method and Some Physicochemical Properties of Extractives of Irvingia Gabonensis Seeds
}

\author{
Ogaji IJ, Nan A', Hoag SW ${ }^{1}$ \\ Departments of Pharmaceutical Technology, University of Jos, Jos, Plateau State, Nigeria, \\ ${ }^{1}$ Pharmaceutical Sciences, School of Pharmacy, University of Maryland, Baltimore, MD, USA \\ Address for correspondence: Prof. Stephen W Hoag; E-mail: shoag@ rx.umaryland.edu
}

\begin{abstract}
The plant Irvingia gabonensis contains lipids and polymer extractives that can be a good source of excipients for oral pharmaceutical formulations. These constituents are usually extracted from the seeds with the aid of either organic solvents or enzymes. The purpose of this paper was to describe a novel, simpler, cheaper, and safer method for the simultaneous extraction of lipids and gum from $I$. gabonensis. A $100.0 \mathrm{~g}$ of seeds of $I$. gabonensis in $200 \mathrm{~mL}$ deionized water was heated at $78^{\circ} \mathrm{C}$ in the presence of $2.0 \mathrm{~g}$ sodium chloride for $1 \mathrm{~h}$, and the mixture was allowed to stand for the lipids to be separated and removed by filtration. The samples were air dried at $25-30^{\circ} \mathrm{C}$. The liquid fraction was centrifuged at $3445 \mathrm{rpm}$ for $30 \mathrm{~min}$, and the supernatant portion containing the gum was freeze dried. The samples were investigated for their true, bulk, and tapped densities as well as particle size and particle size distributions. The rheological, and near infrared absorption spectra as well as thermal behavior of the samples were also studied. The lipid and the polymeric components of I. gabonensis seeds were successfully extracted simultaneously. The true densities of the fatty and gum components were, respectively, 1.000 and $1.544 \mathrm{~g} / \mathrm{cm}^{3}$. The melting point of the fat was $40^{\circ} \mathrm{C}$ and $T_{\mathrm{g}}$ of the gum was $232^{\circ} \mathrm{C}$. These values were similar to those described in the literature for the components using the traditional method, demonstrating the effectiveness and efficiency of this simple novel method.
\end{abstract}

Key words: Gum and fat fractions, Irvingia gabonensis, physicochemical properties, simultaneous extraction

\section{INTRODUCTION}

Irvingia gabonensis (Aubry Lecomte ex. O'Rorke) Baill. commonly known as 'African mango' or 'bush mango' is a tree of $15-40 \mathrm{~m}$, with a bole slightly buttressed. ${ }^{[-4]}$ The

\begin{tabular}{|l|l|}
\hline \multicolumn{2}{|c|}{ Access this article online } \\
\hline Quick Response Code: & \\
\hline & Website: \\
& www.jyoungpharm.in \\
\cline { 2 - 2 } & DOI: \\
\hline & $10.4103 / 0975-1483.96612$ \\
\hline
\end{tabular}

plant is a wild forest tree ${ }^{[3,5]}$ with dark green foliage and yellow fragrant flowers and occurs in the wild lowland forest; two to three trees occur together and in some areas, it is reported to be widespread. I. gabonensis is largely distributed in Africa. ${ }^{[6-9]}$ The fruit is spherical with smooth yellow fibrous mesocarp and hard endocarp when ripe. The seed from the plant has been of interest in the food,,$^{[5,10-12]}$ beverages, ${ }^{[13-15]}$ medical ${ }^{[4,16-21]}$ and pharmaceutical ${ }^{[2-32]}$ as well as cosmetic circles. ${ }^{[33]}$ The seed of the plant contains lipids and polymeric constituents ${ }^{[6,15,34-38]}$ and are usually harvested during the dry season when ripe. The seeds are sold round the year in all markets where food stuffs are sold in Nigeria. It is a common soup ingredient freely 
prepared in any part of Nigeria and many African countries. Both the lipids (also referred to as dika fat or I. gabonensis wax) and the polymeric (gum) components have been used by pharmaceutical scientists as excipients in various formulations. The mucilage from the kernel has been used as a binding agent in tablet formulation, ${ }^{[22]}$ and as a emulsifying and suspending agent. ${ }^{[38,39]}$ On the other hand, the lipid has been employed in tableting as lubricant, ${ }^{[32,40]}$ sustained release ingredient, ${ }^{[23,24,41]}$ microencapsulation, ${ }^{[42]}$ as suppository base ${ }^{[28,29,43]}$ and as a component of film coating operation. ${ }^{[27]}$

The lipids component of I. gabonensis seeds have been traditionally extracted using $n$-hexane ${ }^{[40]}$ or other organic solvents; ${ }^{[43]}$ and more recently an enzymatic method for extracting the lipid components was developed. ${ }^{[44]}$ On the other hand, the polymeric component of the seed has been extracted from aqueous dispersion using petroleum ether ${ }^{[22]}$ or diethyl ether ${ }^{[45]}$ None of the extraction processes described in the literature provided for simultaneous extraction of the lipid and polymer component, which are of interest to pharmaceutical scientists. In addition, organic solvents have many disadvantages such as adverse environmental consequences of their disposal, worker safety concerns, and cost. Thus, the objective of this study was to develop a novel, simple and cost effect method for simultaneous extraction of the lipids and polymeric components and at the same time overcome the disadvantage the use of organic solvents.

\section{MATERIALS AND METHODS}

Irvingia gabonensis seeds were obtained from a main market, Jos, Nigeria; sodium chloride (lot B27630, J. T. Baker, USA).

\section{Methods}

A $100 \mathrm{~g}$ of ground seed of I. gabonensis was accurately weighed (Metler PC 4400) and transferred to a $4 \mathrm{~L}$ beaker containing $2 \mathrm{~L}$ of $1 \% \mathrm{w} / \mathrm{v}$ sodium chloride which was pre-heated to about $78^{\circ} \mathrm{C}$. The mixture was heated on a hot plate to about $78-85^{\circ} \mathrm{C}$. Gentle mixing for an hour was achieved with the aid of a magnetic stirrer. The mixture was left to stand at room temperature $21^{\circ} \mathrm{C}$ for $24 \mathrm{~h}$. Solidification of the lipids component took place at the top and the bottom of the mixture and the lipids were subsequently removed by filtration through a $105 \mu \mathrm{m}$ stainless sieve. The lipids were air dried and stored in air tight container until ready for use. The remaining sample containing the gum was centrifuged (Allegra 6R centrifuge, Beckman Coulter ${ }^{\mathrm{TM}}$, USA) at $3440 \mathrm{rpm}$ for $5 \mathrm{~min}$ to remove proteins and other impurities. The resultant clear supernatant mucilage was dried in a lyophilizer and stored in an air tight container until required for further investigations.

\section{Evaluation of physicochemical properties of extractives from Irvingia gabonensis seeds}

\section{Photomicrograph}

Photomicrographs of the samples were obtained on a Nikon eclipse microscope (Model ME 600, Nikon Instruments Inc., Melville, NY, USA) fitted with a camera interfaced with Spot basic software version 2.41 (Linkam Scientific System, England, UK). The photomicrograph of the sample is displayed on the computer (HP Corporation, USA) and is saved as images in jpeg format until required.

\section{Differential scanning calorimetry}

About 2-10 mg of the sample was transferred to a DSC pan of known weight and was subjected to differential scanning calorimetry studies (model 2950, TA instrument, Delaware USA) at a heating rate of $10^{\circ} \mathrm{C} / \mathrm{min}$ with the aid of ultra pure nitrogen as the purge gas. Thermal information was acquired and analyzed using Universal analysis 2000 software (TA instrument, Delaware USA).

\section{True density}

The samples to be analyzed were dried to about $1 \% \mathrm{w} / \mathrm{w}$ moisture content before the experiment. Prior to running samples on the gas pycnometer, the volume of the sample cell and the expansion volume were taken. Simply, the cup of the gas pycnometer (Model Acupyc 1330, S/N 3902; Micromeritics Instrument Corporation, Norcross, GA, USA) was first cleaned and its weight together with the two bulbs was taken. The main gas supply was turned on and the pressure was set at 20-22.0 psig. The pycnometer chamber cap was removed and greased with Dow Corning vacuum grease with the aid of the greasing disk. The transducer was zeroed. The calibration balls were placed in the cell chamber cup securely. The calibration was accomplished with the balls in the cup as the standard. The sample identification, analysis parameters and report, purge fill pressure, number of runs, run fill pressure and equilibration rate were sequentially imputed. The sample of known weight was introduced, and the readings were taken with the analysis terminating when five consecutive runs were within the specified tolerance or full scale of ten runs were executed. The results were printed on a Hewlett Parker printer (HP, USA) and analyzed. The results displayed were the average of ten determinations.

\section{Bulk and tapped densities}

The United States pharmacopoeia method II for determination of bulk and tapped density was used. Briefly, 
a quantity of the material sufficient enough to complete the test was passed through a $1.00 \mathrm{~mm}$ (size 18) top screen mounted of the Scott Volumeter (ASTM-329-90) apparatus. The powder was allowed to slide and bounce through the glass baffles of the instrument. The sample then passes through the bottom funnel into a cylindrical cup of about $25 \mathrm{~mL}$ until it overflows. The excess powder was gently scrapped off the cylindrical cup by smoothly moving the edge of the blade of a spatula perpendicular to and in contact with the top surface of the cup. Care was taken to keep the spatula perpendicular to prevent packing and removal of the powder from the cup. The bulk density, $\mathrm{g}$ per $\mathrm{mL}$, was calculated by the formula:

Bulk density $=M / V_{\text {o }}$

where $M$ is the mass of the powder and $V_{\mathrm{o}}$ is the volume of the cup. Five determinations were made and the average of such determinations was used.

United States pharmacopoeia method II for tapped density determination was also used in the determination of the tapped density of the samples. The mechanical tapped density test was used to mechanically tap the powder at a fixed drop of $3 \mathrm{~mm}$ and the nominal rate of 250 drops per min. The tapped density is given by the formula:

Tapped density $=M / V_{\mathrm{f}}$

where $M$ is the mass of the powder used and $V_{\mathrm{f}}$ is the tapped volume.

\section{Particle size and size distribution}

The lipid fraction was dispersed in water with the aid of sodium lauryl sulfate to produce a suspension. The particle size and particle size by volume determinations were performed on Malvern Mastersizer- $S^{\circledR}$ (version v2.18, Malvern Instruments, UK) set to $3 \$ \$ D$ (Fraunhofer) presentation and the $300 \mathrm{RF}$ range lens was used. A sample of the suspension was introduced into the liquid dispersion chamber connected to a small volume disperser that keeps the particles uniformly dispersed in the continuous medium. Sufficient quantity of the sample was introduced with the aid of a micropipette to achieve at least an obscuration of about $10 \%$. The data which were acquired with the aid of the Malvern software was then transferred to Microsoft Excel (Microsoft Corporation, USA) for analysis.

In the case of the polymeric portion, Zeta Sizer ${ }^{\circledR}$ (High Performance Particle Sizer, Malvern Instruments, UK) utilizing the dynamic light scattering method was employed to estimate the particle size distribution by volume. The instrument was turned on and allowed for its temperature to stabilize for $30 \mathrm{~min}$. The HPPS software was switched on, and the sample was transferred to a cuvette, filling to a height of $10 \mathrm{~mm}$ with the aid of Fin pipette. The cuvette was inserted and the temperature was allowed to stabilize. The programmed measurement from the software was selected and used for the measurements. The results were saved to the already open measurement database.

\section{Rheological property of the gum fraction}

The rheological characteristics of the gum extracted from I. gabonensis were determined using a Brookfield digital rheometer (model LVDV-III+CP, Brookfield Engineering Laboratories, Inc. Middleboro, MA, USA) using a CPE 40 cup and plate. Prior to the determination of viscosity, the rheometer was zeroed and the gap between the cup and plate was set to $0.013 \mathrm{~mm}$ using the rheometer programmable features. A $1 \mathrm{~mL}$ sample of $3.6 \% \mathrm{w} / \mathrm{v}$ mucilage was transferred to the sample cup and the cup was fixed in position. The viscosity of the sample was determined at spindle speed from 2 to $100 \mathrm{rpm}$ and when subsequently decreased from 100 to $2 \mathrm{rpm}$ at $0.5,1$ and 2 min ramping intervals. The temperature in the system was maintained at $25^{\circ} \mathrm{C}$ with the aid of regulated water bath (Fisher Scientific, USA).

Near infrared spectroscopy

The near infrared (NIR) absorption spectroscopic evaluation was carried out on both fractions using the rapid content analyzer $\left(\operatorname{Vision}^{\circledR} 3.20\right.$, FOSS NIR Systems, Maryland, USA). The performance and linearization checks were carried out according to the procedure in the instrument manual. The powdered sample was transferred to a transparent $20 \mathrm{ml}$ glass vial. The sample was placed on the sample holder and scanned after the reference scan was made. The absorption spectra data obtained were stored in the computer till when required.

\section{RESULTS AND DISCUSSION}

\section{General description of fractions}

Two fractions were obtained from an aqueous dispersion of I. gabonensis using the novel method described; the lipids solidify and were removed by filtration while the gum portion remained in the aqueous dispersion. The lipid fraction was off white to yellowish in color with the yellowish fraction settling at the bottom of the container and the whitish finer portion suspended. On the other hand, the gum fraction was whitish to brownish in color [Figure 1]. 


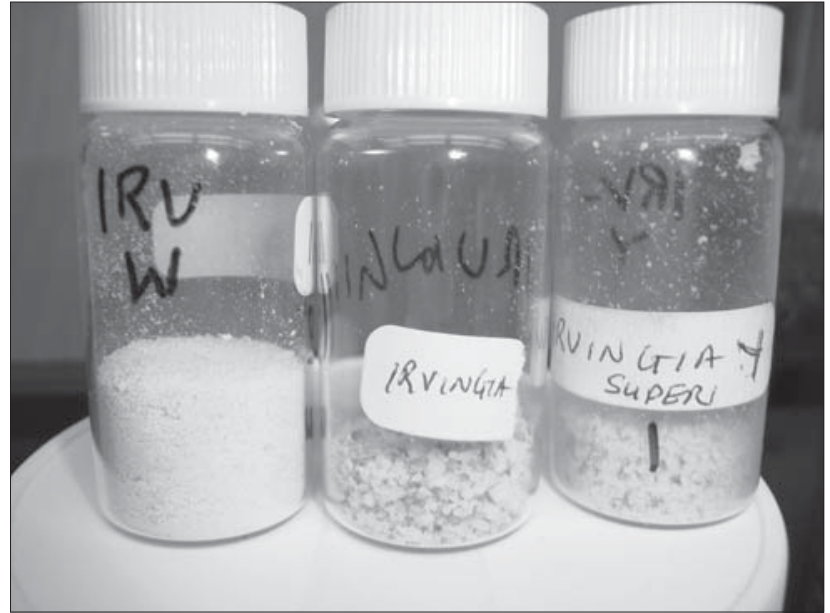

Figure 1: Irvingia fractions (L-R): White lipid fraction (float), aqueous (middle) and yellow lipid (sediment)

\section{Bulk and tapped densities of I. gabonensis gum}

The bulk and tapped densities of the gum were 0.368 and $0.613 \mathrm{~g} / \mathrm{cm}^{3}$, respectively. Bulk and tapped densities of material affect the handling and process method to be adopted when included in a formulation. A material with low tapped density would be difficult to compress while a highly compressible material should have a high tapped density. In the case of Irvingia gum, the tapped density was almost twice that of the bulk suggesting it is highly compressible, a good quality attribute for direct compression operations.

\section{True density}

Table 1 shows that the skeletal density of the lipid fractions was $1.005 \mathrm{~g} / \mathrm{cm}^{3}$ irrespective of the appearance. The true density of the gum was $1.544 \mathrm{~g} / \mathrm{cm}^{3}$. True density values are indicative of the physicochemical properties of the materials, and these values suggest differences between the two fractions from the plant seeds. At the same time, the lipid fraction exhibited a density of about $1.0 \mathrm{~g} / \mathrm{cm}^{3}$ as water and this may explain why the fraction was partially afloat and partially submerged.

\section{Photomicrograph}

The photomicrograph of the gum of I. gabonensis is shown in Figure 2. The particles did not have any definite shape.

\section{Differential scanning calorimetry}

Figure 3 shows the thermograph of the two fractions obtained from I. gabonensis seeds. The melting point and the $T_{\mathrm{g}}$ of the lipid fraction were, respectively, 40.26 and $22.72^{\circ} \mathrm{C}$. The melting point of the fatty component was consistent with those in the literature in which the workers

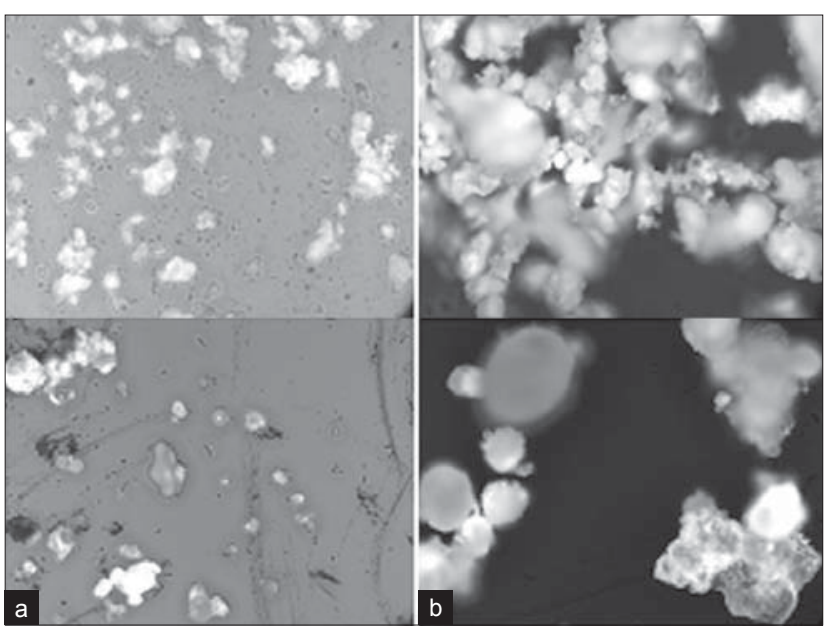

Figure 2: Photomicrographs of Irvingia gabonensis

Table 1: Physicochemical properties of Irvingia gabonensis extractives

\begin{tabular}{lccc}
\hline Description & \multicolumn{2}{c}{ Water insoluble fractions } & Water soluble \\
\cline { 2 - 3 } & White & Yellow & fraction \\
\hline True density $\left(\mathrm{g} / \mathrm{cm}^{3}\right)$ & $1.0055 \pm 0.000$ & $1.0050 \pm 0.000$ & $1.544 \pm 0.000$ \\
${ }_{\mathrm{p}} \mathrm{H}(3.6 \% \mathrm{w} / \mathrm{v})$ & - & - & $6.76 \pm 0.21$ \\
Z-average $(\mathrm{nm})$ & - & - & $1309.5 \pm 18.6$ \\
polydispersity index & & - & $0.483 \pm 0.07$ \\
Bulk density $\left(\mathrm{g} / \mathrm{cm}^{3}\right)$ & - & - & $0.368 \pm 0.028$ \\
Tapped density $\left(\mathrm{g} / \mathrm{cm}^{3}\right)$ & - & & \\
Distribution moments & & & \\
Mean volume & $63 \pm 7.4$ & & \\
Standard deviation & $101 \pm 13.51$ & & \\
Skewness & $2.51 \pm 0.11$ & & \\
Kurtosis & $6.73 \pm 0.78$ & & \\
Distribution percentile & & & \\
$(\mu \mathrm{m})$-Volume \% & & & \\
10 & $1.76 \pm 0.08$ & & \\
20 & $3.74 \pm 0.19$ & & \\
50 & $17.02 \pm 1.95$ & & \\
80 & $97.77 \pm 10.94$ & & \\
90 & $196.72 \pm 24.48$ & & \\
Distribution modal & & & \\
sizes $(\mu \mathrm{m})$ & & & \\
1 & & & \\
2 & $5.10 \pm 0.16$ & & \\
3 & $0.33 \pm 0.00$ & & \\
\hline
\end{tabular}

used $n$-hexane as the extractive solvent. ${ }^{[40]}$ On the other hand, the $T_{\mathrm{g}}$ of the polymeric fraction was $232.5^{\circ} \mathrm{C}$, similar to the value obtained by some other workers. ${ }^{[4]}$

\section{Near-infrared spectroscopy}

Near-infrared spectroscopy has great potential in providing real-time chemical information. ${ }^{[4]}$ The most prominent absorption bands occurring in the NIR region are related to overtone and absorption bands of the fundamental molecular vibrations of $-\mathrm{CH},-\mathrm{NH}$, and $-\mathrm{OH}$ functional groups observed in the mid-spectra region. ${ }^{[48]}$ Figure 4 shows 
the NIR spectra of the gum and the lipids from I. gabonensis seeds. Each of these samples exhibited the $-\mathrm{CH}_{3}$ functional group at $2300 \mathrm{~nm}$ in the combination band region. It seemed that $-\mathrm{ArCH}$ is present in the gum fraction as shown in the first overtone peaks at $1700 \mathrm{~nm}$ while $-\mathrm{CH}_{2}$ and $-\mathrm{CH}_{3}$ were predominant at this wavelength in the lipid fractions. The $\mathrm{CH}$ group was stronger in the gum than in the lipid in the second overtone. The spectra of the gum extract from the conventional method was different from those of the gum by this novel method at $1100 \mathrm{~nm}$ but showed the same pattern at $2300 \mathrm{~nm}$, which may be due to higher quality of the sample from the novel extraction method. This difference in peaks at $110 \mathrm{~nm}$ between the two samples may be related to impurities in the conventional fraction, as that peak was similarly present in water insoluble fractions. NIR measurements are performed without dilution or the requirements of short optical path lengths or dispersion in nonabsorbing matrices that are necessary with traditional spectroscopic methods of analysis such as UV-VIS or mid-NIR spectroscopies. NIR spectra can be collected in either transmittance or reflectance mode. In general, transmittance (log $I / T)$ measurement

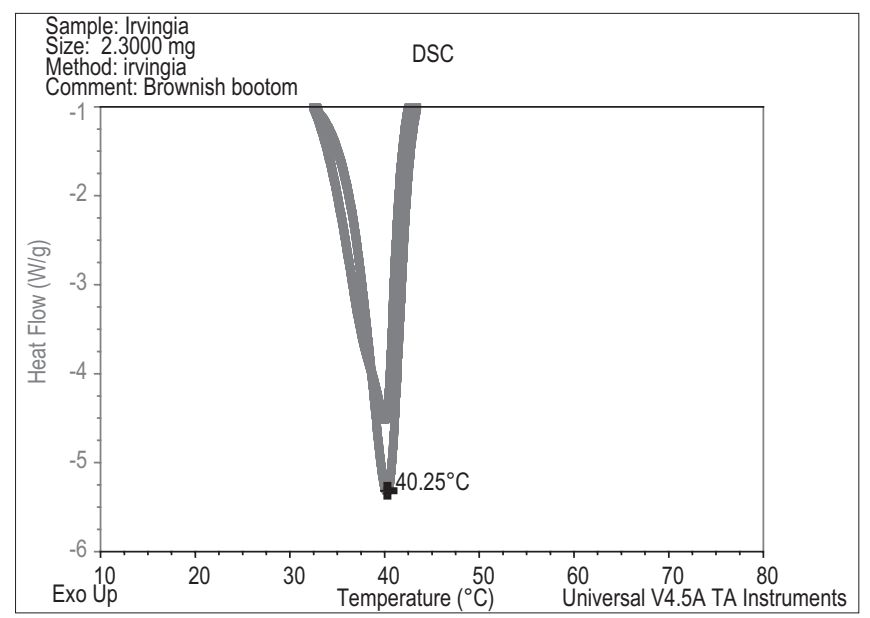

Figure 3a: DSC thermogram of Irvingia gabonensis (dika fat) is performed on translucent samples. Diffuse reflectance $(\log I / R)$ measurements are performed on opaque or light scattering matrices such as slurries, suspensions, paste, or solids and in this study, diffuse reflectance was used.

In either measurement mode, it is difficult to identify unique spectra features related to individual component within a given matrix. To enhance spectra features and compensate for baseline offsets, it is common practice in NIR spectroscopy to apply a mathematical pre-treatment to the spectra. Frequently, the second derivative of the absorbance data, with respect to wavelength, is calculated. In the second derivative data, absorbance maxima are converted to minima with positive side-lobes. The apparent spectra bandwidth is also sharply reduced, allowing for resolution of overlapping peaks and the baseline difference between spectra are largely eliminated. The presentation of the data as the second derivative and not raw spectra was based on this understanding.

\section{Particle size and particle size distribution by volume}

The particle size distribution by volume is shown in

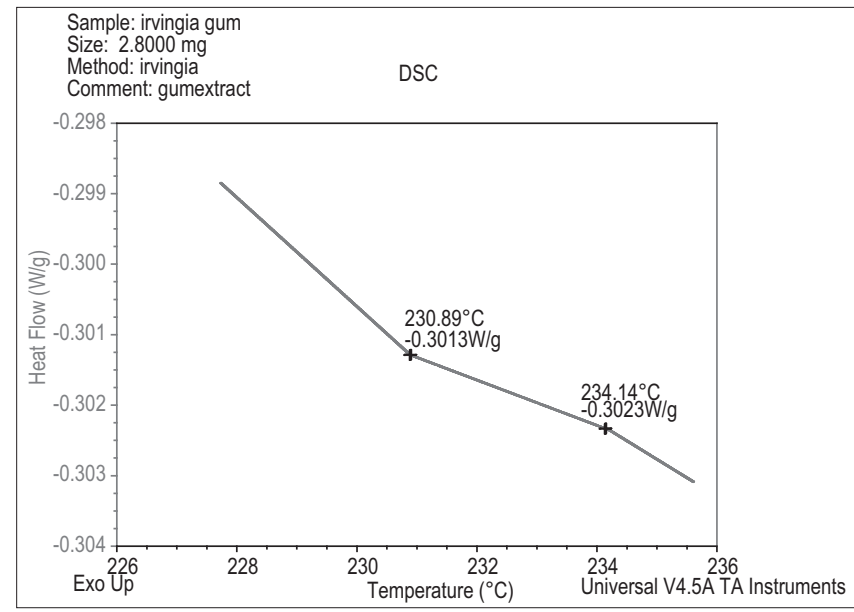

Figure 3b: DSC thermogram of Irvingia gum fraction

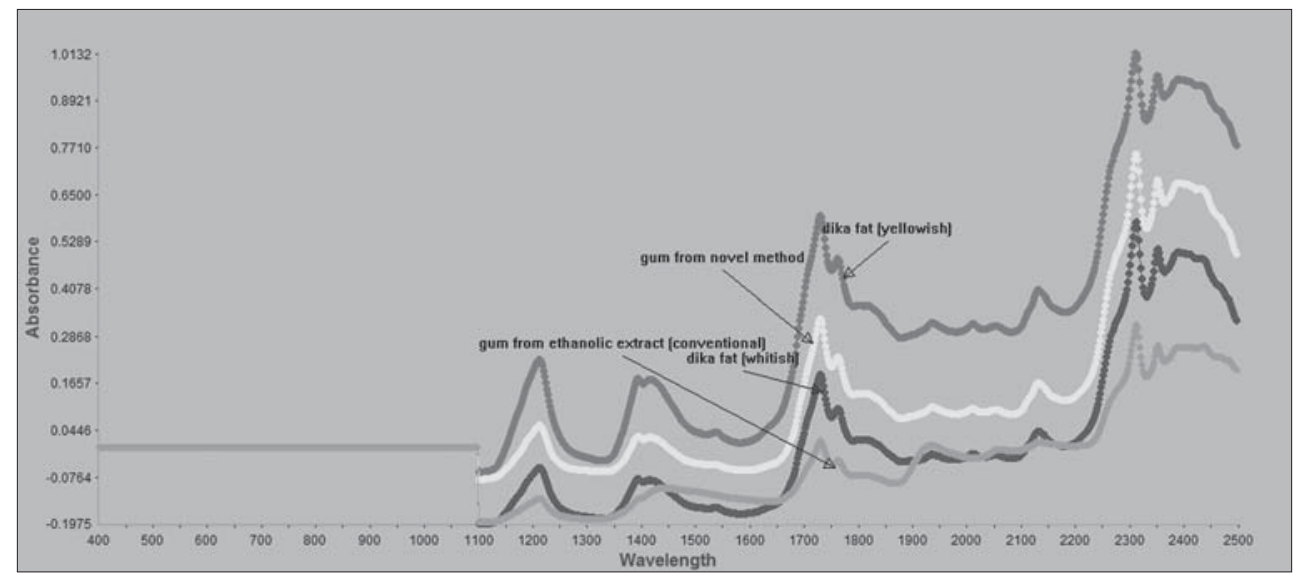

Figure 4: NIR spectra of Irvingia extractives 


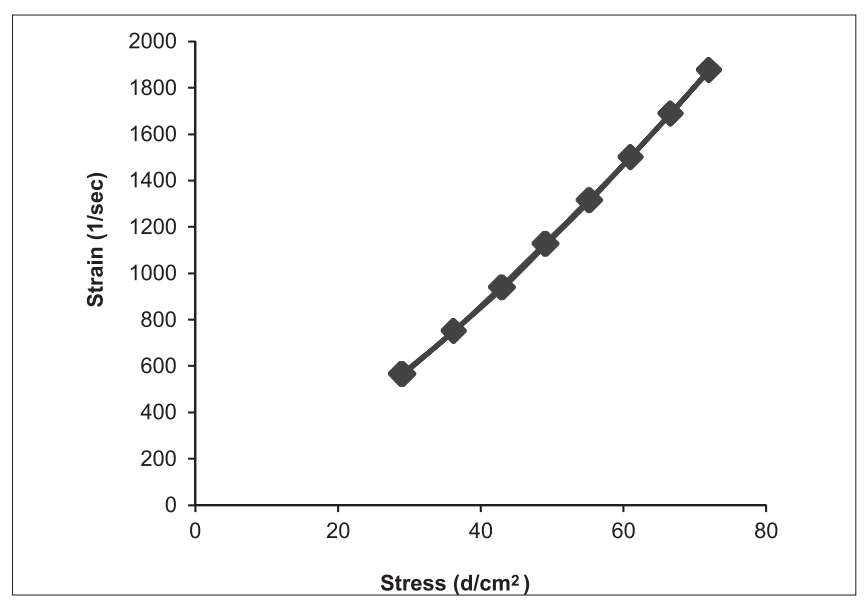

Figure 5: Relationship between the strain and stress of Irvingia gum $(3.6 \% \mathrm{w} / \mathrm{v})$

Table 1 for the fractions. The particle size of the lipid mass ranged from 0.1 to about $500 \mu \mathrm{m}$, and the mean volume in the distribution moments was $63.15 \pm 7.40 \mu \mathrm{m}$ while the corresponding values of the particle surface and length were, respectively, 3.45 and $0.45 \mu \mathrm{m}$. Distribution percentile by volume and distribution modal sizes are also shown in Table 1.

On the other hand, the z-average of the gum was $1309 \mathrm{~nm}$ with a polydispersity of 0.483 . In dynamic light scattering, this z-average size is the most important and stable number produced by the technique and can be used for quality control purposes. Using the same instrument, it is possible to compare samples of materials with respect to the particle size by either volume or intensity. In this study, the low solubility of the extract using the conventional extraction method, for example, in the case of the gum limited such a comparison. No measurement of the r-average of the gum has been reported in the literature.

\section{Rheological properties}

Figure 5 shows the relationship between stress and strain while Figure 6 shows the relationship between speed and apparent viscosity of the gum. The viscosity of I. gabonensis gum $(3.6 \% \mathrm{w} / \mathrm{v})$ ranged between 3.85 and $5.19 \mathrm{cP}$ with speed variation between 75 and $250 \mathrm{rpm}$. The rheological profile of the gum was pseudoplastic. This was similar to the results obtained previously. ${ }^{[12]}$

\section{CONCLUSION}

In conclusion, simultaneous extraction of lipids and polymeric portions of I. gabonensis was successfully carried out simultaneously using a method that was simple, safer, and

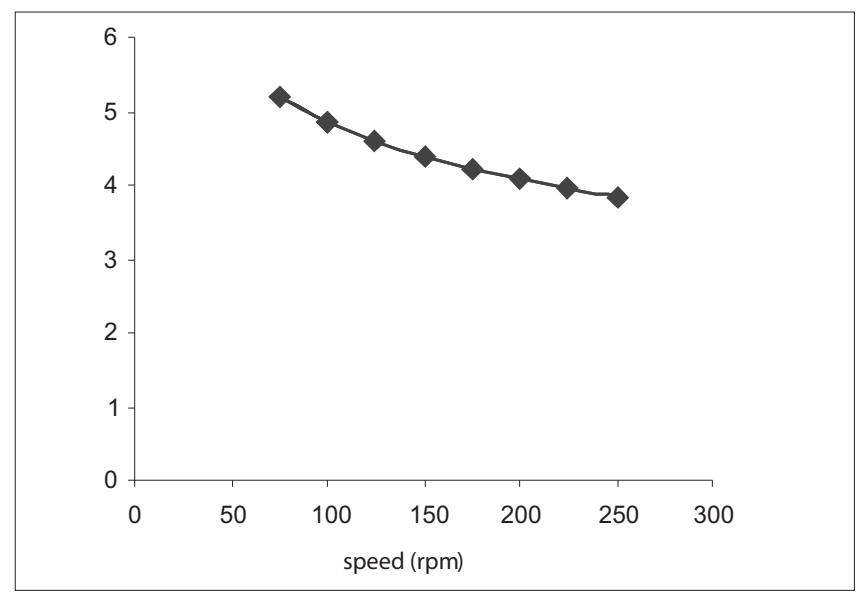

Figure 6: Relationship between spindle speed and the viscosity of Irvingia gum $(3.6 \% \mathrm{w} / \mathrm{v})$

less expensive than the traditional use of $n$-hexane to extract the lipids. The method combined simplicity and safety with efficient removal of impurities from the gum fraction. The physicochemical properties of the extractives were evaluated, and the results showed similarities in the extractives obtained by this method and those obtained by conventional methods.

\section{REFERENCES}

1. Joseph JK. Physico-chemical attributes of wild mango (Irvingia gabonensis) seeds. Bioresour Technol 1995;53:179-81.

2. Joseph K, Aworh OC. Composition, sensory quality and respiration during ripening and storage of edible wild mango (Irvingia gabonensis). Int J Food Sci Technol 1991;26:337-42.

3. Joseph K, Aworh OC. Post-harvest treatment of wild mango (Irvingia gabonensis) for improved shelf life. Food Chem 1992;44:45-8.

4. Kuete V, Wabo GF, Mbaveng AT, Metuno R, Etoa FX, Tchaleu Ngadjui B, et al. Antimicrobial activity of the methanolic extract, fractions and compounds from the stem bark of Irvingia gabonensis (ixonanthaceae). J Ethnopharmacol 2007;114:54-60.

5. Aina JO. Physico-chemical changes in African mango (Irvingia gabonensis) during normal storage ripening. Food Chem 1990;36:205-12.

6. Eka O. Proximate composition of bush mango tree and some properties of dika fat. Niger J Nutr Sci 1980;1:33-6.

7. Abbiw D. Useful plants of Ghana. Kew, London: Intermediate Technology Publications and the Royal Botanical Garden; 1990.

8. Atangana AR, Ukafor V, Anegbeh P, Asaah E, Tchoundjeu Z, Fondoun JM, et al. Domestication of Irvingia gabonensis: 2 . The selection of multiple traits for potential cultivars from Cameroon and Nigeria. Agroforestry Syst 2002;55:221-9.

9. Ayuk ET, Duguma B, Franzel S, Kengue J, Mollet M, Tiki-Manga T, et al. Uses, management and economic potential of Irvingia gabonensis in the humid lowlands of Cameroon. Forest Ecol Manag 1999;113:1-9.

10. Adeyeye EI, Arogundade LA, Akintayo ET, Aisida OA, Alao PA. Calcium, zinc and phytate interrelationships in some foods of major consumption in Nigeria. Food Chem 2000;71:435-41.

11. Onyeike EN, Olungwe T, Uwakwe AA. Effect of heat-treatment and defatting on the proximate composition of some Nigerian local soup thickeners. Food Chem 1995;53:173-5.

12. Uzoma A, Ahiligwo RN. Studies on the rheological properties and functional potentials of achi (Brachystega eurycoma) and ogbono (Irvingia gabonesis) seed gums. Food Chem 1999;67:217-22.

13. Akubor PI. The suitability of African bush mango juice for wine production. Plant Foods Hum Nutr 1996;49:213-9. 


\section{Ogaji, et al:: Some physicochemical properties of Irvingia gabonensis seed extractives}

14. Fajimi O, Sarumi MB, Olayode MN, Gamra EO, Sanusi SI. in vitro propagation of Irvingia gabonensis. Afr J Biotechnol 2007;6:976-8.

15. Giami SY, Okonkwo VI, Akusu MO. Chemical composition and functional properties of raw, heat-treated and partially proteolysed wild mango (Irvingia gabonensis) seed flour. Food Chem 1994;49:237-43.

16. Raji Y, Ogunwande IA, Adesola JM, Bolarinwa AF. Anti-diarrhegenic and anti-ulcer properties of Irvingia gabonensis in rats. Pharm Biol 2001;39:340-5.

17. Njoku OU, Ugwuanyi JO. Nutritional and toxicological properties of dika fat (Irvingia gabonensis). J Herbs Spices Med Plants 1997;4:53-8.

18. Ngondi JL, Oben JE, Minka SR. The effect of Irvingia gabonensis seeds on body weight and blood lipids of obese subjects in Cameroon. Lipids Health Dis 2005;4:12.

19. Nguyen-Pouplin J, Tran H, Tran H, Phan TA, Dolecek C, Farrar J, et al. Antimalarial and cytotoxic activities of ethnopharmacologically selected medicinal plants from South Vietnam. J Ethnopharmacol 2007;109:417-27.

20. Ozolua RI, Eriyamremu GE, Okene EO, Ochei U. Hypoglycemic effects of viscous preparations of Irvingia gabonensis (dikanut) seeds in streptozotocininduced diabetic wistar rats. J Herbs Spices Med Plants 2006;12:1-9.

21. Wolfe OA, Ijeoma UF. Effects of aqueous extracts of Irvingia gabonensis seeds on the hormonal parameters of male guinea pigs. Asian Pac J Trop Med 2010;3:200-4.

22. Odeku OA, Patani B. Evaluation of dika nut mucilage (Irvingia gabonensis) as a binding agent in metronidazole tablet formulation. Pharm Dev Technol 2005;10:439-46.

23. Ofoefule SI, Chukwu A. Effects of polyethyleneglycol 4000 and sodium lauryl sulphate on the release of hydrochlorothiazide embedded in the dika fat matrix. Acta Pharm 2001;51:233-9.

24. Ofoefule SI, Chukwu A, Okore VC, Ugwah MO. Use of dika fat in the formulation of sustained release frusemide encapsulated granules. Boll Chim Farm1997;136:646.

25. Okafor JC. Varietal delimitation in Irvingia gabonensis (Irvingiaceae). Bull Jardin Bot Natl Belg 1975;45:211-21.

26. Okolo CO, Johnson PB, Abdulraham EM, Abdu-Aguye I, Hussaini IM. Analgesic effects of Irvingia gabonensis stem bark extract. J Ethnopharmacol 1995;45:125-9.

27. Okore VC. Effect of dika fat content of a barrier film coating on the kinetics of drug release from swelling polymeric systems. Boll Chim Farm 2000;139:21-5.

28. Okore VC. Evaluation of dika fat as a suppository base II: Thermal and release characteristics of blended dika fat suppositories. Drug Dev Ind Pharm 1994;20:93-100.

29. Okore VC. Evaluation of dika fat as a suppository base: Factors which affect the drug release from dika fat-based suppositories. Acta Pharm 1998;48:39-46.

30. Okore VC, Udeala OK. GC-MS analysis of fatty acids of Irvingia gabonensis seed fat. Niger J Nat Prod Med 2004;1:43.

31. Onyechi JO. Preformulation compatibility screening of dika fat-drug mixtures using differential scanning calorimetry. Bioresearch 2009;7(1):465-469

32. Onyechi JO, Udeala OK. The tabletting properties of dika fat lubricant. Drug Dev Ind Pharm 1990;16:1203-16.
33. Tairu AO, Hofmann T, Schieberle P. Studies on the key odorants formed by roasting of wild mango seeds (Irvingia gabonensis). J Agric Food Chem 2000;48:2391-4.

34. Abdurahman EM, Rau PP, Shok M, Olurinola PF, Laakso I. Analysis of the fatty acid composition of the seed fat of two varieties of Irvingia gabonensis by high resolution gas chromatography. J Pharm Res Dev 1996;1:49.

35. Amubode FO, Fetuga BL. Amino acid composition of seeds of some lesser known tree crops. Food Chem 1984;13:299-307.

36. Lewkowitsch J. Dika fat. Analyst 1905;30:394-5.

37. Meara ML, Patel CB. The component acids and glycerides of dika fat. J Sci Food Agric 1950;1:48-51.

38. Ndjouenkeu R, Akingbala J, Oguntimein G. Emulsifying properties of three African food hydrocolloids: Okra (Hibiscus esculentus), dika nut (Irvingia gabonensis), and khan (Belschmiedia sp.). Plant Foods Hum Nutr 1997;51:245-55.

39. Isimi CY, Kunle O, Bangudu AB. Some emulsifying and suspending properties of the mucilage extracted from kernels of Irvingia gabonensis. Boll Chim Farm 2000;139:199-204.

40. Udeala OK, Onyechi JO, Agu SI. Preliminary evaluation of dika fat, a new tablet lubricant. Drug Dev Ind Pharm 1980;32:6-9.

41. Umekoli GC, Onyechi JO, Udeala OK. Use of dika fat in the formulation of sustained release theophylline tablets and capsules. Bioresearch 2009;7(1):456-460

42. Udeala OK, Aly SA. The effect of microencapsulation with dika wax on the degradation and dissolution of aspirin tablets. Drug Dev Ind Pharm 1986;12:397-421

43. Megwa SA. Evaluation of dika fat as a suppository base. Drug Dev Ind Pharm 1987;13:2731-48.

44. Womeni HM, Ndjouenkeu R, Kapseu C, Mbiapo FT, Parmentier M, Fanni J. Aqueous enzymatic oil extraction from Irvingia gabonensis seed kernels. Eur J Lipid Sci Technol 2008;110:232-8.

45. Dudu PO, Okiwelu SN, Lale NE. Attractancy of diethyl ether extracts of Arachis hypogaea (Linnaeus) (Papilionaceae), Citrullus lanatus (Thunberg) (Cucurbitaceae) and Irvingia gabonensis var. excelsa (Baillon) (Irvingiaceae) to Oryzaephilus mercator (Fauvel) (Coleoptera: Silvanidae). J Stored Prod Res 1998;34:237-41.

46. Attama A, Akpa PA. Determination of the amorphicity and glass transition temperature ( $\mathrm{Tg}$ ) of some natural polysaccharides. J Drug Deliv Sci Technol 2008;18:219-20.

47. Osborne BG, Fearn T, Hindle PH. Practical NIR Spectroscopy. Harlow: Longman; 1993.

48. Wesley IJ, Larsen N, Osborne BG, Skerrit JH. Non invasive monitoring of dough mixing by near infrared spectroscopy. J Cereal Sci 1998;27:61-9.

How to cite this article: Ogaji IJ, Nan A, Hoag SW. A novel extraction method and some physicochemical properties of extractives of Irvingia gabonensis seeds. J Young Pharmacists 2012;4:66-72.

Source of Support: Nil, Conflict of Interest: None declared. 